\title{
An Integrated Curriculum for Technical Writing in Higher Education in China
}

\section{Prof. Feifei Zhong, Southwest Jiaotong University}

Mrs. Feifei Zhong is a lecturer teaching non-English majors English in the School of Foreign Languages, Southwest Jiaotong University, Chengdu, China. She received her Master's degree in Applied Linguistics from Southwest Jiaotong University in 2007 and joined Southwest Jiaotong University since then. Her research interest is in effective English learning strategies. She was the first place winner of universitywise Teaching Competition in 2007 and 2013.

\section{Prof. Gene Hou, Old Dominion University}

Dr. Gene Hou is a Professor in the Department of Mechanical and Aerospace Engineering of Old Dominion University (ODU). He received his PhD in Mechanical Engineering from University of Iowa in 1983 and joined Old Dominion University since then. His expertise is in computational mechanics, multidisciplinary design optimization and system integration and risk management. He is the co-director of the Marine Dynamics Laboratory. During his tenure, he has the privilege of developing 3 new undergraduate and 6 new graduate courses in the areas related to computational methods and design. 


\title{
An Integrated Curriculum for Technical Writing in Higher Education in China
}

\author{
Feifei Zhong ${ }^{1}$ and Gene $\mathrm{Hou}^{2}$ \\ ${ }^{1}$ Department of Engineering English, School of Foreign Languages \\ Southwest Jiaotong University \\ Chengdu, China, 611756 \\ zhongfeifei@163.com \\ ${ }^{2}$ Department of Mechanical and Aerospace Engineering \\ Old Dominion University \\ Norfolk, VA 23529 \\ ghou@odu.edu
}

\begin{abstract}
This study aims to develop an effective curriculum plan to improve technical writing in higher education in China. The paper first investigated the deficiency in the curriculum design in China for English technical writing by comparing the required courses offered in Southwest Jiaotong University (SWJTU) in China with those in Old Dominion University (ODU) in US. Questionnaires and interviews were then conducted among studying abroad Chinese students, visiting scholars, English as Second Language (ESL) instructors as well as engineering professors. The collected data revealed that the oversea Chinese students were struggled more with higher order concerns in writing than lower order ones. This comparison and survey led to the development of a curriculum plan that includes both Chinese and English writing classes for all majors in an engineering college in China.
\end{abstract}

Key Words: Technical Writing; Higher Education in China; Higher Order Concerns (HOCs); Lower Order Concerns (LOCs)

\section{Introduction}

This paper focuses on exploring an effective solution to improve technical writing in higher education in China. Technical writing is in many occasions considered as a subset of a broader term, technical communication. In this study, technical writing is specifically referred to as a term that represents an increasingly broad set of activities designed to communicate understandable information that can enhance productivities ${ }^{1}$. As long as our modern society needs to go forward, technical writing will be indispensable. The terms, Lower Order Concerns (LOCs) and Higher Order Concerns (HOCs), which are commonly used in technical writing literature are defined here for later use in this paper. The definitions are taken from the handout presented by Purdue's Online Writing Lab ${ }^{2}$. LOCs refer to voice/tone, sentence structure, punctuation, usage of words and spelling, while HOCs refer to ideas, focus, organization and development or evidence.

Technical writing is highly valued in universities in US and western countries. A survey for those graduates from engineering departments at the State University of New York at Buffalo showed that each student spent at least $32 \%$ of their college time on technical writing. ${ }^{3}$ Technical writing is valued as the basic skill for the US higher education, professional research as well as daily career work. It is tightly embedded in the college education throughout the curriculum in 
the US. Consequently, almost every university in US offers courses on technical writing. An engineering student can't graduate without taking the required technical writing classes.

Universities in China on the contrary, pay little attention to technical writing which is just a writing course irrelevant to any major. Many universities in China do offer English classes which however, emphasize more on vocabularies, sentence structures, grammars, etc. These courses don't teach English technical writing in general nor in their specific field. Only few universities in China recognize the importance of technical writing. For examples, Fudan, Qinghua, Shandong and Peking University do offer Technical Writing courses, which however are elective.

In 2006, professors from University of Science and Technology pointed out that the popularity of technical communication in China had not yet reached the level of the end of 19th century in the US ${ }^{4}$. The research, teaching and practice of technical communication in China were almost non-existent. The academic discipline of Technical Writing was confined to English teaching as a minor course of ESP (English for Specific Purposes) without any support from systematic research and education ${ }^{5}$. To improve China's Technical Writing education is an imperative and pressing issue.

On the one hand, according to the International Monetary Fund, China became the world's largest economy in 2014. Its huge population and economic potential have made China one of the most important markets in the world. Today, the economic potential of China is attracting a growing number of world-class foreign enterprises, including SAP, HP, and Microsoft, which have started to specifically tailor products and services for Chinese users and customers ${ }^{6}$. There will be more and more international communications between China and other countries in different fields. Technical writing is the basic skill required to meet such a need. When students graduate and start to work, technical writing will be useful for documenting sophisticated products or services in order to market the company's brand name. As indicated by Leydens, $20 \%$ to $40 \%$ of the work hours are spent in writing for engineers in the first few years in their career, which increases to $50 \%$ to $70 \%$ when they are promoted to middle management positions and over $70 \%$ and even to $95 \%$ when in senior management positions. This reflects the fact that technical writing is a skill set providing a life-long career benefit ${ }^{7}$. Thus, technical writing should be included in the curriculum throughout the whole higher education system. On the other hand, numbers of Chinese students are growing to study abroad, especially going to English speaking countries such as US and UK. According to the news ${ }^{8}$, the number of international students in US reached over one million in 2016. Among all international students, the largest student body comes from China, which takes $31 \%$ of the total number. Meanwhile, reported by Sina News in Hongkong ${ }^{9}$, British Prime Minister Theresa May recently mentioned in her Chinese New Year greeting that 150,000 Chinese international students are studying in the UK in 2017. In order to prepare Chinese students better for their overseas study, enhancing Technical Writing education becomes in fact an essential and urgent issue.

Some researchers had suggested teaching Technical Writing in places other than 4-year Chinese universities. Barnum et al. considered postsecondary vocational training schools as possible homes for technical communication training, because such schools focus on "applied subjects" such as industry, medicine, and finance ${ }^{10}$. However, students in these schools don't have the English proficiency at the level to manage English Technical Writing courses. 
Other researchers suggested offering Technical Writing class to those majored in English. $\mathrm{Yu}^{5}$, for example, suggested the curricular design for English majors as follows. In the freshman year, students are required to take introductory language courses that address reading, listening, and speaking skills. These courses are what the Chinese educators call English for General Purpose (EGP) courses. In the sophomore year, students continue taking EGP courses, which include advanced reading, listening, and speaking as well as introductory writing courses. But during this phase, the focus will be more on grammar, vocabulary, sentence writing and paragraph writing. In the junior year, students continue taking advanced EGP writing. Meanwhile, they read original English texts and write feedbacks with longer essays. In the senior year, students will gain discipline writing skill through industry internship and a senior thesis. This is a curriculum clearly designed for English majors. However, teaching technical writing should not be limited to just English majors. Students in all different majors should grasp this skill to better serve their future career or study.

The first author of this paper has been a college English teacher in China for more than 9 years. Students in her class often complained that they are already overwhelmed by their majorrelated courses. As such, they are unable to put English learning as their priority. Ironically, it is their English communication skill that can advance them in their careers.

In light of the above, this study is aiming to find the most practical way to implement Technical Writing curriculum in China based upon the currently available resources. The proposed Technical Writing curriculum will be built upon the existing curriculum in SWJTU. It is planned for students learning LOCs through the current English language classes, while learning HOCs through the Chinese writing classes. It will require students to practice Technical Writing throughout the entire 4-year curriculum in their major related laboratory or research reports, either in English or in Chinese. The detailed proposal will be elaborated in Section V.

\section{Comparisons of Curriculum Designs}

Though a general comment on Technical Writing curriculum in higher educations in both US and China has been made early, a more detailed elaboration will be made hereafter by investigating the course paths in the Batten College of Engineering and Technology at Old Dominion University (ODU) in the US and those in Southwest Jiaotong University (SWJTU) in China.

All departments in the Batten College of Engineering and Technology at ODU follow very similar course path in training students' technical writing skills. Students need to take writing courses from the English Department as well as their major-related department. For an example, Fig. 1 shows the course path of the Civil Engineering Department. The courses that emphasize on technical writing in the Civil Engineering department including ENGL 110C English Composition, CEE 111 Information Literacy and Research, ENGL 211C English Composition, one of literature courses and CEE 403W Civil Engineering Design Project and Professional Practice. The literature requirement can be fulfilled by selecting any of the following classes: Understanding World Literature, American Writers, American Experiences, Introduction to Literature and Literature Way of Knowing. As for CEE 403W, it is a writing intensive course which requires students to practice project report writing in their major disciplines based upon the Technical Writing principles. 
As indicated in Fig.1, ENGL 110C is offered by the English Department to all freshmen in their first semester. In the second semester, students take CEE 110 to conduct research and write reports related to Civil Engineering subjects. This class is taught by the faculty in the Civil Engineering Department. Both courses, Literature and ENGL 211C, are offered to students in sophomore and junior years which are offered by faculty in the English Department. In senior year, students take a writing intensive course CEE $403 \mathrm{~W}$ delivered by professors from the Civil Engineering department. This technical writing training will prepare students to conduct research and write their senior design project report.

\begin{tabular}{|c|c|c|c|}
\hline \multicolumn{4}{|c|}{$\begin{array}{l}2015 \text { - } 2016 \text { Old Dominion University Catalog } \\
\text { Bachelor of Science in Civil Engineering } \\
\text { his is a sample four year curriculum with a suggested ondering of courses. Students have the flexibility of ne-ordering as needed. }\end{array}$} \\
\hline \multicolumn{4}{|c|}{ YEAR 1 - FRESHMAN (33 CREDITS) } \\
\hline \multicolumn{2}{|c|}{ FALL SEMESTER (16 credits) } & \multicolumn{2}{|c|}{ SPRING SEMESTER (17 credits) } \\
\hline General Education Coursewwork: & Credit Hours & General Education Coursework: & Credit Hours \\
\hline MATH 211 & 4 & MATH 212 & 4 \\
\hline CHEM $121 \mathrm{~N}$ & 3 & CHEM $123 \mathrm{~N}$ & 3 \\
\hline CHEM $122 \mathrm{~N}$ & 1 & PHYS $231 \mathrm{~N}$ & 4 \\
\hline ENGL $110 \mathrm{C}$ ( $\mathrm{C}$ or better required) & 3 & $\operatorname{CS} 150$ & 4 \\
\hline ENGN 110 & 2 & CEE 111 & 2 \\
\hline \multirow[t]{2}{*}{ Human Creativity } & 3 & & \\
\hline & \multicolumn{3}{|c|}{ YEAR 2 - SOPHOMORE (34 CREDITS) } \\
\hline \multicolumn{2}{|c|}{ FALL SEMESTER (18 credits) } & \multicolumn{2}{|c|}{ SPRING SEMIESTER (16 credits) } \\
\hline General Education Coursework: & Credit Hours & General Education Coursework: & Credit Hours \\
\hline CEE 204 & 3 & CEE 220 & 3 \\
\hline PHYS $232 \mathrm{~N}$ & 4 & MAE 205 & 3 \\
\hline MATH 312 & 4 & CEE 219 & 1 \\
\hline BIOL $110 \mathrm{~N} / 111 \mathrm{~N}$ or OEAS $111 \mathrm{~N}$ & 4 & ENGL $211 C$ ( $C$ or better required) & 3 \\
\hline \multirow{2}{*}{ COMM $101 R$} & 3 & MATH 307 & 3 \\
\hline & & Literature & 3 \\
\hline \multicolumn{4}{|c|}{ YEAR 3 - JUNIOR (31 CREDITS) } \\
\hline \multicolumn{2}{|c|}{ FALL SEMESTER (15 credits) } & \multicolumn{2}{|c|}{ SPRING SEMESTER (16 credits) } \\
\hline Maior Coursework: & Credit Hours & Maior Coursework: & Credit Hours \\
\hline CEE 320 & 3 & CEE 310 & 3 \\
\hline CEE 305 & 3 & CEE 323 & 3 \\
\hline CEE 330 & 3 & CEE 340 & 3 \\
\hline CEE 350 & 3 & CEE 335 & 1 \\
\hline \multirow[t]{3}{*}{ CEE 304} & 3 & CEE 240 & 3 \\
\hline & & Interpreting the Past & 3 \\
\hline & \multicolumn{2}{|c|}{ YEAR 4 - SENIOR (32 CREDITS) } & \\
\hline \multicolumn{2}{|c|}{ FAIL SEMESTER (17 credits) } & \multicolumn{2}{|c|}{ SPRING SEMESTER (15 credits) } \\
\hline Maior Coursewonk: & Credit Hours & Maior Coursework: & Credit Hours \\
\hline CEE 470 & 3 & CEE 403W (C or better required) & 3 \\
\hline CEE 410 & 3 & CEE $4 \mathrm{XX}$ & 3 \\
\hline CEE 430 & 3 & $\begin{array}{l}\text { CEE } 4 X X \text { - Transportation or } \\
\text { Environmental }\end{array}$ & 3 \\
\hline ENGN 401 & 1 & ENMA 480 (Satisfies Philosophy and Ethics) & $\beta$ \\
\hline CEE 402 & 1 & Upper Division General Education & 3 \\
\hline Human Behavior & 3 & & \\
\hline $\begin{array}{l}\text { Upper Division General Education } \\
\text { TOTAL CREDIT HOURS: } 130\end{array}$ & 3 & & \\
\hline
\end{tabular}

Figure 1. Course Path for Civil Engineering Major ${ }^{11}$

Course paths related to Technical Writing of all engineering departments at ODU are summarized in Table 1. Descriptions of all of these courses can be found in Appendix, which are taken from the school course catalog ${ }^{12}$. The table clearly reveals a similar trend for all engineering majors. Note that ENGL $231 \mathrm{C}$ is a Technical Writing class offered by faculty in the English Department. The number of the credit hours of each course is followed by the course name with a dash in between. Every department allocates 14 credit hours, out of 130 credits in total to graduate, dedicated to writing and literature classes. It's obvious that training of writing 
is all the way from the first year till the last year for all engineering students in ODU. The emphasis of the courses is changed gradually from basic writing to major-related writing. These courses are delivered by faculty from English department as well as major-related departments as it is shown in Table 1.

Table 1. English Writing Course Paths of Engineering Departments at ODU

\begin{tabular}{|l|l|l|l|l|}
\hline \multicolumn{1}{|c|}{ Dept. } & $\begin{array}{l}\text { Civil } \\
\text { Engineering }\end{array}$ & $\begin{array}{l}\text { Mechanical } \\
\text { Engineering }\end{array}$ & $\begin{array}{l}\text { Electrical } \\
\text { Engineering }\end{array}$ & $\begin{array}{l}\text { Computer } \\
\text { Engineering }\end{array}$ \\
\hline $1^{\text {st }}$ Semester & ENGL 110C-3 & ENGL 110C-3 & ENGL 110C-3 & ENGL 110-3 \\
\hline $2^{\text {nd }}$ Semester & CEE 111-2 & MAE 111-2 & ECE 111-2 & ECE 111-2 \\
\hline $3^{\text {rd }}$ Semester & & & & Literature-3 \\
\hline $4^{\text {th }}$ Semester & $\begin{array}{l}\text { ENGL 211C-3; } \\
\text { Literature-3 }\end{array}$ & ENGL 231C-3 & ENG 231C-3 & ENG 231C \\
\hline $5^{\text {th }}$ Semester & & Literature-3 & & \\
\hline $6^{\text {th }}$ Semester & & & Literature-3 & \\
\hline $7^{\text {th }}$ Semester & & MAE 434W-3 & & ECE 484W-3 \\
\hline $8^{\text {th }}$ Semester & CEE 403W-3 & & ECE 485W-3 & \\
\hline
\end{tabular}

For the sake of comparison, the course paths in English writing of engineering departments in SWJTU in China were collected and presented in Table 2. This table lists only the courses that are directly related to English writing or Technical Writing. It amounts to 10 credit hours in total, out of 180 credit hours to graduation. The links of the course paths related to the full curriculum of SWJTU are given in reference ${ }^{13}$.

Table 2. English Writing Course Paths of Engineering Departments at SWJTU

\begin{tabular}{|l|l|l|l|l|}
\hline \multicolumn{1}{|c|}{ Dept. } & $\begin{array}{l}\text { Civil } \\
\text { Engineering }\end{array}$ & $\begin{array}{l}\text { Mechanical } \\
\text { Engineering }\end{array}$ & $\begin{array}{l}\text { Electrical } \\
\text { Engineering }\end{array}$ & $\begin{array}{l}\text { Computer } \\
\text { Engineering }\end{array}$ \\
\hline 1st Semester & English I-4 & English I-4 & English I-4 & English I-4 \\
\hline 2nd Semester & English II-2 & English II-2 & English II-2 & English II-2 \\
\hline 3rd Semester & $\begin{array}{l}\text { Selective } \\
\text { English } \\
\text { Course-2 }\end{array}$ & $\begin{array}{l}\text { Selective } \\
\text { English } \\
\text { Course-2 }\end{array}$ & $\begin{array}{l}\text { Selective } \\
\text { English Course- } \\
\text { 2 }\end{array}$ & $\begin{array}{l}\text { Selective } \\
\text { English } \\
\text { Course-2 }\end{array}$ \\
\hline 4th Semester & $\begin{array}{l}\text { Selective } \\
\text { English } \\
\text { Course-2 }\end{array}$ & $\begin{array}{l}\text { Selective } \\
\text { English } \\
\text { Course-2 }\end{array}$ & $\begin{array}{l}\text { Selective } \\
\text { English Course- } \\
\text { 2 }\end{array}$ & $\begin{array}{l}\text { Selective } \\
\text { English } \\
\text { Course-2 }\end{array}$ \\
\hline 5th - 8th Semester & \multicolumn{4}{|c|}{ None } \\
\hline
\end{tabular}

English I and II are general English courses, including listening, speaking, reading and writing with equal importance. The formats of these courses are similar to those offered in high school, which do not emphasize Technical Writing. 
Selective English Courses include a set of 7 courses: Academic English; Workplace English; Thinking and Academic Skills-Audio, Visual and Oral English; Communicating and Cultural-Audio Visual and Oral English; English Composition; British or American Literature Classics; and English III. Students are required to select one of these selective English courses in the $3^{\text {rd }}$ semester and another one in the $4^{\text {th }}$ semester. Among those courses, Academic English, Workplace English, English Composition, and British or American Literature Classics may directly or indirectly relate to Writing or Technical Writing. English III is a continuation of English II, but only for students who fail to pass the CET-4 test. CET-4 refers to College English Test Band 4, which is the lowest English proficiency requirement for college students.

The last course in the full course paths of those departments in SWJTU is Graduation Dissertation course. It is the same as the senior capstone project design course in ODU. But it is not a regular classroom class. It is done individually between a student and his or her project advisor and it doesn't include any technical writing requirement, nor writing intensive training as did in ECE 485W in Electrical Engineering or CEE 403W in Civil Engineering in ODU.

\section{Reasons of Deficiencies in Technical Writing Instruction in Higher Education in China}

As discussed in Section II, the engineering curriculum at ODU emphasizes on technical Writing training in 11 out of 130 required credits for graduation which is in sharp contrast to the common practice in China. Technical Writing has long been overlooked in China. Lack of attention happens in different sectors, including: policy makers in the education field, teachers from primary schools all the way to the universities, and students themselves. This lack of attention also results in deficiencies in expertise and resources for teaching Technical Writing in Chinese and English, doing research on Technical Writing, writing quality learning materials and training technical communicators.

Ding ${ }^{14}$ mentioned that because of the complete lack of attention, Chinese college students do not study technical writing or disciplinary writing even in Chinese. China's prolonged negligence of Chinese composition happens not only in college but postsecondary schools which is a stark contrast to mandatory writing courses in most high schools and universities in US. That is a main contributor to the deteriorating writing skills of Chinese college graduates. If college students couldn't write well with their native language, how can they be expected to be good in writing with a second language?

Well-trained technical communicators are enormously unavailable in China. Although some universities offer a few courses on technical communication as we mentioned in the Introduction section, so far no Chinese university offers a comprehensive program in technical communication. Therefore, companies use workarounds to do Technical Writing. ${ }^{15}$

Universities that recognize the need for technical writing may encounter difficulties in finding a capable administrator to develop the program, recruiting qualified professors to teach the related courses as well as finding adequate instruction materials to support the teaching. Nationwide, only a few university professors and lecturers regard technical writing as their area of expertise. Although Peking University is one of the few universities in China that already recognize the potential significance of Technical Communication, only one textbook became available in China until 2014, which is "A Practical Guide to Scientific and Technological Writing (Chinese version)", published by the ZTE group-a big IT company in China. ${ }^{15}$ 


\section{Responses of Surveys}

The current curriculums in Old Dominion University in the US and Southwest Jiaotong University in China were displayed and discussed in Section II. The reasons of deficiencies of technical writing in Higher Education in China were also presented in Section III. This section will conduct interviews or surveys of individuals in academia to measure the current state of technical writing in China based upon personal experiences. The persons involved in this investigation include professors and ESL (English as Second Language) teachers, grant writer and international students on campuses in US. It is expected that such a survey can provide an insight of deficiency in technical writing, which may lead a reasonable improvement plan.

IV.1. Interviews with ESL teachers, US professors, and Grant Writers

(i) Interviews with ESL teachers who have taught undergraduate students at ODU who haven't passed TOEFL and GRE. The question asked is "What are the problems exhibited in Chinese students' writing?" The collected answers are categorized mainly into two groups based on LOCs and HOCs.

$\underline{\text { LOCs }}$

$\underline{\mathrm{HOCs}}$

- Lack of organization: writing lack of structured sentences or paragraphs, unable to use proper vocabulary

- Indirect expression: Chinese students, unlike American students, write a lot of foreshadows before they reach to the point.

- Lack of critical thinking: Critical thinking refers to a person taking a Yes or No position on something, and giving reasons on why taking that position. American students are trained to think critically very early in their education, but Chinese students are lack of critical thinking which may relate to their traditional, social, and cultural background. They rather take ideas from others to be more conservative than present their own ideas in a creative or critical way. Plagiarism shows a lack of ideas.

(ii) Interviews with professors who teach undergraduate and graduate students in ODU who have already passed TOEFL and GRE.

Eight professors from four departments in the Batten College of Engineering and Technology are interviewed. All these eight professors have over thirty years of experience teaching international students in the university. The questions put forth to them are "What are the problems exhibited in Chinese international students' writing?" and "What are the suggestions for the improvement?" Their answers are categorized into four groups. The first two, LOCs and HOCs, are associated with students' writing and the rest are suggestions for improvement.

$\underline{\text { LOCs }}$

- Lack of ideas won't be affected too much in their writing quality if their English language capability reaches to a certain threshold. 
$\underline{\text { HOCs }}$

- Although lack of ideas wouldn't be affected too much on their writing as long as they reach a certain threshold of their LOCs, their ways of thinking and structure synthesis are still very oriental, not critical enough.

Design of Curriculum

- Students in China should have English courses teaching them how to write, following the international standard.

Improvement of Teachers

- Train or hire more qualified teachers. This indicates the needs for the advanced level of training on teachers.

(iii) Interview with a professional grant writer who edits grant proposals for professors at ODU.

The question posted to the grant writer is "What are the common mistakes found in the grant writings, submitted by foreign-born faculty?" Again, the answers are categorized into two groups based on LOCs and HOCs.

$\underline{\text { LOCs }}$

- They often forget the article "the", which happens more with the foreign professors.

- Sequence of the words in a sentence often followed by the common practices used in their native languages.

$\underline{\mathrm{HOCs}}$

- The standard structure of Abstract/Summary-Intro-Material \& Method-ResultsConclusion-Reference was not fully observed in their proposal writings.

- Their writings have problems with the flow of the article. It means that connecting phrases or sentences are missing between paragraphs.

- The sentences may be fluffy or verbose. It means that the ideas presented in the sentences may not be easily understood by others.

In a summary, the results of interviews with professors, ESL teachers and grant writer at ODU indicated that LOCs is an important threshold for technical writing. However, it is the HOCs highlighted as the priority for a good technical writing.

IV.2. Questionnaire with the Chinese international students and visiting scholars from China at ODU

In order to collect feedbacks from Chinese international students and visiting scholars about their personal experience about technical writing, a questionnaire was made online. Responses from 54 students and visiting scholars from China were collected. Among the 54 students and scholars, 43 (79.63\%) of their major belong to natural science and 11 (20.37\%) belong to social science. The questions asked are related to the difficulties they encountered in technical writing. They were asked to rank the difficulties 0 to 5 they encountered in 9 specific categories in Technical Writing in which 0 is low and 5 is high. Their backgrounds are shown in Table 3, while the outcomes of their answers are given in Table 4. 
Table 3. Majors of the Respondents

\begin{tabular}{|l|l|l|}
\hline Category & Percentage\% & Number \\
\hline Undergraduate & $48.15 \%$ & 26 \\
\hline Graduate(master) & $18.52 \%$ & 10 \\
\hline Graduate(PhD) & $9.26 \%$ & 5 \\
\hline Scholars(college teachers in China) & $24.07 \%$ & 13 \\
\hline
\end{tabular}

Table 4. Outcome of Survey on Difficulty in Writing

\begin{tabular}{|l|l|l|l|l|l|l|l|}
\hline \multirow{2}{*}{$\begin{array}{l}\text { Problems } \\
\text { L: LOCs } \\
\text { H:HOCs }\end{array}$} & \multicolumn{5}{|c|}{$\begin{array}{l}\text { Percentage of Each Scale \% } \\
\text { Scale: 0-5 }\end{array}$} \\
\cline { 1 - 8 } Scales from 0-5 & 0 & 1 & 2 & 3 & 4 & 5 & \\
\hline Voice/Tone (L) & $12.96 \%$ & $33.33 \%$ & $16.67 \%$ & $24.07 \%$ & $5.56 \%$ & $7.41 \%$ & 1.98 \\
\hline Sentence Structure (L) & $12.96 \%$ & $22.22 \%$ & $16.67 \%$ & $25.93 \%$ & $18.52 \%$ & $3.7 \%$ & 2.26 \\
\hline Usage of Words (L) & $0 \%$ & $18.52 \%$ & $11.11 \%$ & $38.89 \%$ & $20.37 \%$ & $11.11 \%$ & 2.94 \\
\hline Spelling of Words (L) & $18.52 \%$ & $40.74 \%$ & $9.26 \%$ & $18.52 \%$ & $5.56 \%$ & $7.41 \%$ & 1.74 \\
\hline Idea (H) & $1.85 \%$ & $20.37 \%$ & $24.07 \%$ & $31.48 \%$ & $14.81 \%$ & $7.41 \%$ & 2.59 \\
\hline Focus (H) & $5.56 \%$ & $20.37 \%$ & $20.37 \%$ & $27.78 \%$ & $18.52 \%$ & $7.41 \%$ & 2.56 \\
\hline Organization (H) & $7.41 \%$ & $24.07 \%$ & $29.63 \%$ & $18.52 \%$ & $14.81 \%$ & $5.56 \%$ & 2.26 \\
\hline Development (H) & $11.11 \%$ & $18.52 \%$ & $18.52 \%$ & $27.78 \%$ & $16.67 \%$ & $7.41 \%$ & 2.43 \\
\hline Evidence (H) & $12.96 \%$ & $24.07 \%$ & $9.26 \%$ & $31.48 \%$ & $16.67 \%$ & $5.56 \%$ & 2.31 \\
\hline
\end{tabular}

In Table 4, the first four problems: Voice/Tone, Sentence Structure, Usage of Words, and Spelling of Words belong to the Lower Order Concerns (LOCs), while the last five: Idea, Focus, Organization, Development and Evidence belong to the Higher Order Concerns (HOCs). Based on the mean value given in the last column, 2 out of 4 LOCs are above 2, and 2 out of 4 LOCs are below 2. The ones above 2 are Sentence Structure and Usage of Words. The "Usage of Words" has the highest mean among all the problems, which indicates that students need to practice more writing with better qualified Technical Writing instructors in their related majors. Meanwhile, all the HOCs are above 2. This survey presents the weakness in LOCs such as sentence structure and usage of words, and an overall weakness in HOCs. It can be concluded that generally speaking, HOCs are ignored in China. This survey indicates the urgent needs to improve HOCs in the Higher education in China, which will be the focused point in developing a curriculum plan to improve Technical Writing in China.

IV.3. Essay Examples from Chinese Students in China

Five sophomore students from Southwest Jiaotong University in China were randomly chosen in 2015 to write an essay entitled, "Comparison of 3 Smart Phones: Apple, Samsung, and Xiaomi". These five students are majored in Mechanics, Applied Physics, Geographic Information System, Railway Traffic Signaling and Control and Electric Engineering. All these 
five students were the top $20 \%$ in their respective English learning classes. They have relatively better language skills in LOCs such as grammar, choice of words, sentence structure, etc. But most of their essays still have problems with the HOCs. Only two students can write it clearly with Abstract, Keywords, Bibliography and the clear structure of Intro-Body-Conclusion, Furthermore, only these two students can use Table or Graphs properly to summarize the results of comparison. Detailed evaluation of their essays is shown in Table 5: in which "Yes" indicates it is included, while "No" isn't.

Table 5. Evaluation of Essay Writing

\begin{tabular}{|l|l|l|l|l|l|}
\hline Student & Abstract & Keywords & Bibliography & $\begin{array}{l}\text { Intro-Body- } \\
\text { Conclusion }\end{array}$ & Table/Graphs \\
\hline A & Yes & Yes & Yes & Yes & Yes \\
\hline B & No & No & No & No & No \\
\hline C & Yes & Yes & Yes & Yes & Yes \\
\hline D & No & No & No & Yes & No \\
\hline E & No & No & No & No & No \\
\hline
\end{tabular}

To summarize all those interviews, surveys and samples, it is found that although LOCs problems existing in Chinese international students and scholars at different stages of their academic career paths, HOCs have long been their weakness in their technical writing.

\section{Proposals for Improvement}

Since China adopted its open policy in 1979, it has enormously expanded its economic and technical exchanges with other countries and regions, but the improvement in the education on technical writing is not noticeable. Research papers on technical writing gave solutions mainly on either implementing English Technical Writing course in postsecondary vocational training schools or in English majors' curriculum or recruiting qualified teachers in Technical Writing. Conceptually, these are good ideas, but not practical enough for implementation. The changes in education on Technical Writing proposed here will place priority in implementation practicality and finance consideration. The proposal for improvement addresses three major concerns: Change of Mindset, Curriculum Revision and Professional Development.

\section{V.1. Change of Mindset}

The philosophy that technical writing is for learning and critical thinking ${ }^{16}$ should be built in the mindset of policy makers, teachers and students in China. For a long time, Chinese students often consider writing as an assignment, instead of a process to help them learn and form critical thinking capability. According to the article 5 Reasons Why Your Students Should Write Every Day, writing can reinforce recently learned material, encourage use of imagination, explore possibilities, extend learner's experience and make surprising discoveries ${ }^{17}$. 
The responsibilities of teaching technical writing shouldn't be limited within the English Department. At ODU, the English writing intensive courses are embedded in each of the engineering departments and taught by the faculty in their major field. The university also sets up the Technical Writing Center independently from any college and department, serving the entire university. It is responsible to organize training workshop, provide editing service and e-mail out "Weekly Writing Tips" to the whole faculty body.

\section{V.2 Four Year Curriculum Plan on Technical Writing}

In technical writing, LOCs are the basis, while HOCs are necessary for the writing to reach to an international standard. Teaching HOCs is a major challenge that technical writing education in China faces. It is proposed in this paper that HOCs should be included in higher education in China, not only in English writing, but also in Chinese writing.

Engineering students in SWJTU in China don't take any Chinese language class, let alone having Chinese writing course offered by the Chinese department. This situation is very different from the course paths at ODU, in which 2 out of 4 writing-related courses were conducted by English department. Considering English is American students' native language, its role will be similar to Chinese for Chinese students. Chinese writing course usually is not offered in the college as educators take native language for granted; assuming Chinese is too easy for students. But in order to gain technical writing skills, one needs to be trained in his own native language, just like all the American students need to learn technical writing in English.

Therefore, a better way is to offer a common course, Introduction of Technical Writing in Chinese, conducted by the Chinese Department to all the freshmen in the first semester of their college study. The course should be conducted according to the international standard in technical writing. HOCs will be introduced to students and emphasized throughout this course. Since Chinese is the native language, the idea of technical writing in general and HOCs in particular, can be introduced to Chinese students in a more efficient way.

English department should then start to offer the course Introduction of Technical Writing in English in the second semester. With the technical writing principles being introduced in the first semester in Chinese, English technical writing in both LOCs and HOCs should be relatively easier for students to deal with in the second semester. The currently offered English I, II, III, and IV can be revised to gradually shift the weight in writing training from LOCs to HOCs.

In the second and third year, technical writing should be embedded in all of students' major related courses. Students' laboratory reports and course papers should all be completed according to the principles of technical writing. Since no language teacher is involved in teaching students' technical writing in those major-related courses, teachers from engineering disciplines should shoulder all the responsibilities of students' technical writing training. Thus, training for faculties' technical writing skills and their ability of implementing technical writing principles in their classes is very important in this regard.

Table 6 lists the proposed course path for the training of technical writing in both Chinese and English. The alphabet $\mathrm{E}$ in the parenthesis next to each of the classes listed in the table indicates that the class is offered by the English department, while $\mathrm{C}$ by the Chinese department and $\mathrm{M}$ by the major department. The number next to the alphabet indicates the number of 
required credits. In the table, English I, II, III, and IV are English courses remaining focus on LOCs at the beginning and gradually shift to HOCs. Introduction to Technical Writing in Chinese and Introduction to Technical Writing in English are two new courses added to the Engineering curriculum which focus on HOCs. Two credit hours writing intensive class is added to the curriculum in the senior year to prepare all students to write their graduation paper. This will be a common lecture class. It should be conducted by faculty in the respective department. These two credit hours are taken from the existing 8 credit hours of the existing Graduation Dissertation. In short, this proposed curriculum represents a four-year effort to train students in technical writing in their major fields. It only introduces 4 extra credit hours added to the existing curriculum plan; 2 in Introduction to Technical Writing in Chinese and 2 in Introduction to Technical Writing in English. That will amount to 22 credit hours in writing out of 180 credits required for graduation in SWJTU.

Table 6. Proposed Course Path for Technical Writing Training

\begin{tabular}{|c|c|c|}
\hline & First Semester & Second Semester \\
\hline Freshman & $\begin{array}{ll}\text { - } & \text { English I (E-4), } \\
\text { - } & \text { Introduction to Technical Writing } \\
& \text { in Chinese (C-2) }\end{array}$ & $\begin{array}{ll}\text { - } & \text { English II (E-4), } \\
\text { - } & \text { Introduction to Technical } \\
& \text { Writing in English (E-2) } \\
\end{array}$ \\
\hline Sophomore & - English III (E-4), & - English IV (E-4) \\
\hline Junior & \multicolumn{2}{|c|}{ Class Assignments for Lab and Class Project Reports } \\
\hline Senior & $\begin{array}{l}\text { - Technical Writing for Senior } \\
\text { Project Design (M-2) }\end{array}$ & \\
\hline
\end{tabular}

\section{V.3. Opportunities for Professional Development}

On each campus, a Technical Writing center should be established to lead and serve the university-wide effort to Technical Writing training and improvement. This is particularly important, as the class size of a typical classroom in China is about twice of that in US. It requires skillful faculty and teaching assistants to achieve teaching effectiveness in a crowded classroom. Furthermore, Chinese universities should be encouraged to participate in or organize more international conferences on Technical Writing so as to establish more collaborative researches of Technical Writing and to attract more cooperation with companies home and abroad.

Domestically, tcworld China is the premier technical communication event for decisionmakers and professionals in the field of technical communication from various industry sectors. tcworld organized the first international conference for technical communicators and language professionals in China in the year $2015^{18}$.

Internationally, The Society for Technical Communication is the world's largest and oldest professional association dedicated to the advancement of the field of technical communication $^{19}$. The organization traces its roots to the Society of Technical Writers in Boston and the Association of Technical Writers and Editors in New York. Both were founded in the United States in 1953. These organizations merged in 1957 to form the Society of Technical Writers and Editors. In 1960, this group merged with the Technical Publishing Society, based in 
Los Angeles, to become the Society of Technical Writers and Publishers. In 1971, the name of the organization was changed to the Society for Technical Communication. With membership of more than 6,000 technical communicators, it's the largest organization of its type in North America. The society publishes a quarterly journal and a magazine ten times a year and hosts an annual international conference Technical Communication Summit.

\section{Conclusion}

As China plays a more and more important role in the world, it needs to strengthen its ties with the rest of the world and it will create an increasing demand for technical communication. As indicated in this study, Technical Writing in China has been improved slowly over the past 27 years since its reform. To accelerate the improvement in Technical Writing in China, it is very much in need to find a more practical approach that is based on the current infrastructure

This paper proposed a three-point plan to improve Technical Writing training in China: Change of Mindset, Four-Year Curriculum Plan on Technical Writing and Opportunities for Professional Development. The four-year curriculum plan aims to improve Chinese students' Technical Writing skills both in Chinese and in English. It also suggests a trans-disciplinary collaboration which is new in China but necessary in order to allow students combine their professional knowledge with the writing skill they obtained.

This paper represents as an initial investigation to improve Technical Writing in China. It calls for changes in policy and infrastructure to implement Technical Writing-related courses in English and Chinese. An assessment program will be developed shortly afterward to evaluate the outcome of the proposed changes.

\section{References:}

1. Alred, Gerald J. (2015). The Handbook of Technical Writing, 11th Edition, by Bedford/St. Martin's.

2. Purdue OWL (2013). "Higher Order Concerns (HOCs) and Lower Order Concerns (LOCs)", Purdue Online Writing Lab. (https;//owl.english.purdue.edu/)

3. Krauss, R. and McGee, S. J. (2012). "Improving the Assessment of Technical Writing in Senior Design”, presented at ASEE IL/IN Sectional Conference, held at Valparaiso University, Valparaiso, Indiana on March 17, 2012.

(http://ilin.asee.org/Conference2012/Papers/KraussTechWriting.pdf )

4. Li, Shannon. (2014). "Technical Communication Education Taking Roots in China", (http://sigmatechnology.se/news/technical-communication-education-taking-roots-in-china/)

5. Yu, H. (2011). "Integrating Technical Communication Into China's English Major Curriculum”, Journal of Business and Technical Communication, 25(1), 68-94. 
6. Wang, H. (2015). "Technical Communication Development in China", retrieved from the University of Minnesota Digital Conservancy, (http://hdl.handle.net/11299/172230)

7. Leydens, J. A. (2008), "Novice and Insider Perspectives on Academic and Workplace Writing: Toward a Continuum of Rhetorical Awareness, ", IEEE Transactions on Professional Communication, 51(3), 242-263.

8. ChinaNews. (2016). "US International Students Over One Million, Number of Chinese International Students Trumps", Chinanews.com, (http://www.chinanews.com/gj/2016/1116/8064202.shtml

9. Gov.UK (2017). "Theresa May Greeting Chinese People in Mandarin during Chinese New Year, Hoping to Visit China Again", Gov.UK, https://www.gov.uk/government/news/chinese-new-year-2017-theresa-mays-message)

10. Barnum, C. M. and Li, H. L. (2006). "Chinese and American Technical Communication: A Cross-Cultural Comparison of Differences”, Applied Research 58(2), 143-166.

11. Link of 2015 - 2016 Old Dominion University Catalog Bachelor of Science in Engineering Technology (Civil Engineering Technology) https://www.odu.edu/content/dam/odu/offices/advising-transfer/curriculum-sheets/20152016/eng/2015-en-cet-bs.pdf

12. Link of full course paths for different departments of Batten College of Engineering and Technology https://www.odu.edu/success/programs/finishin4\#tab1484=3

13. The links of the course paths related to the full curriculum of SWJTU https://www.odu.edu/content/dam/odu/offices/advising-transfer/curriculum-sheets/20152016/eng/2015-en-civilengineering-bs.pdf https://www.odu.edu/success/programs/finishin4\#tab1484=3 http://202.115.67.4//download/plan/2016/1481534255288.pdf http://202.115.67.4//download/plan/2016/1481514535784.pdf

14. Ding, H. L. (2010). "Technical Communication Instruction in China: Localized Programs and Alternative Models", Technical Communication Quarterly, 19(3), 300-317.

15. Gao, Z. J., Yu, J. S. and Jong, M. de, (2014). "Establishing Technical Communication as a Professional Discipline”, (http://www.tcworld.info/e-magazine/technicalcommunication/article/establishing-technical-communication-as-a-professional-discipline/.)

16. Bean, J. C. (2011). Engaging Ideas: the Professor's Guide to Integrating Writing, Critical Thinking, and Active Learning in the Classroom, 2nd Edition, by Jossey-Bass, A Wiley Imprint.

17. Walker, Sherrelle. (2012). "5 Reasons Why Your Students Should Write Every Day", Scientific Learning, http://www.scilearn.com/blog/5-reasons-students-should-write-every$\underline{\text { day }}$

18. Tcworld. (2015). "tcworld China 2015 The State of the Art of Technical Communication", tekom, http://conferences.tekom.de/tcworld-china-2015/tcworld-china-2015/

19. https://en.wikipedia.org/wiki/Society_for_Technical_Communication 


\section{Appendix Course List for English and English Writing}

ENGL 110C. English Composition. 3 Credits.

The principal objective of the course is to prepare students to be effective writers of the kinds of compositions they will be called on to produce during their college careers. By the end of the course, students should be more mature in their understanding and use of language, should develop efficient writing processes, and should know and demonstrate the qualities of effective composition in a given rhetorical situation. Prerequisites: A passing grade on the Writing Sample Placement Test.

CEE 111. Information Literacy and Research. 2 Credits.

This course will introduce students to the needs, access, evaluation, use, impact and ethical/legal aspects of information, as well as to the application of information literacy and research in the fields of civil and environmental engineering. Prerequisite: ENGN 110

MAE 111. Mechanical and Aerospace Engineering Information Literacy and Research. 2 Credits.

This course will introduce students to the needs, access, evaluation, use, impact and ethical/legal aspects of information, and to the application of information literacy and research in the fields of mechanical and aerospace engineering. Prerequisites: ENGN 110.

ECE 111. Information Literacy and Research for Electrical and Computer Engineering. 2 Credits.

An introductory course for ECE students that explores information literacy in terms of information basics, information need, searching, locating, and evaluating information sources, citing and ethics of information in relation to development and implementation of electrical and computer engineering projects. Prerequisites: ENGN 110 and MATH 162M.

ENGL 211C. English Composition. 3 Credits.

This course emphasizes critical reading, thinking, and writing. Students are introduced to principles of analysis and argumentation and taught the requisite skills that will allow them properly to paraphrase, summarize, and synthesize research in the common modes of academic writing. The course culminates in the preparation of a fully-documented research paper. A student with credit for ENGL 111C cannot receive credit for ENGL 211C. Prerequisites: ENGL $110 \mathrm{C}$ with a grade of $\mathrm{C}$ or higher.

ENGL 231C. Introduction to Technical Writing. 3 Credits.

This course emphasizes critical reading, thinking, and writing as they apply to the technical and scientific disciplines. Students are introduced to principles of analysis and argumentation and taught the requisite skills that will allow them properly to paraphrase, summarize, and synthesize research as it applies to and is most commonly found in the technical and scientific communities. 
The course culminates in the preparation of a fully-documented research paper. A student with credit for ENGL 131C cannot receive credit for ENGL 231C. Prerequisites: ENGL 110C.

\section{Literature.}

This includes ENGL 112L, ENGL 114L, FLET 100L and Literature Way of Knowing. Students need to choose one of those courses conducted by English Department.

- ENGL 112L. Introduction to Literature. 3 Credits.

This course shows the general student how to understand the distinctive forms and meanings of poems, plays, short stories and fiction, and key notions such as character, plot, and imagery. Through critical reading, analysis, class and small group discussions, formal essays and examinations, students will develop an understanding of the effective use of the English language and its contribution to our cultural heritage. Works include women and minority writers.

- $\quad$ ENGL 114L. American Writers, American Experiences. 3 Credits.

This course introduces the student to the diversity of American culture as depicted in American literature. Works include minority and women writers and provide visions of city, frontier and regional life; ethnic and racial immigrant experiences; religion, democracy, can capitalism. A student with credit for ENGL 144L cannot receive credit for ENGL 114L.

- $\quad$ FLET 100L. Understanding World Literature. 3 Credits.

This multicultural course introduces the student to the forms and meanings of poems, stories, novels, and plays from around the world. It provides students with the skills necessary for the appreciation and comparative analysis of these works both as literature and as representations of rich and diverse cultural values. A primary focus of the course will be the role of culture in the formation of national and individual identity, paying special attention to gender, sexuality, race, and class. All works will be read in English.

- CEE 403W. Civil Engineering Design Project and Professional Practice. 3 Credits.

For graduating seniors only. Group design project of civil engineering systems requiring synthesis, data gathering, preliminary investigation, master planning, conceptual designs, layouts, support studies, cost estimates and report writing. Emphasis will be on alternatives, constraints, economics, ethics and professional practice, business and project management, public policy and leadership. (This is a writing intensive course.) Prerequisite: grade of C or better in ENGL 211C or ENGL 221C or ENGL 231C.

- MAE 434W. Project Design and Management I. 3 Credits.

This course prepares students to complete their design projects in MAE 435. Lecture topics include engineering economics; project planning; costing and risk analysis; and product realization techniques. Course involves written and oral presentations for students to improve communication and teamwork skills. (qualifies as a CAP experience) (This is a writing intensive course.) Corequisite: MAE 433. Prerequisites: A grade of $\mathrm{C}$ or better in MAE 332, ENGL 211C or ENGL 221C or ENGL 231C. 
- ECE 485W. Electrical Engineering Design I. 3 Credits.

Part one of the senior capstone design experience for electrical engineering majors. Lectures focus on providing professional orientation and exploration of the design process. Small group design projects focus on the development of electronic subsystems. Oral and written communication skills are stressed. (This is a writing intensive course.) (qualifies as a CAP experience) (offered fall, spring) Prerequisites: ECE 313 and a grade of $\mathrm{C}$ or better in ENGL 211C or ENGL 221C or ENGL 231C. Pre- or corequisite: ECE 303, ECE 304, ECE 323, and ECE 332.

- ECE 484W. Computer Engineering Design I. 3 Credits.

Emphasis is on the design of a complex digital circuit and microcontroller interfacing. A semester-long project involves the design, simulation and testing of a digital architecture and software GUI. Several moderate scale digital modules are designed, simulated, implemented and tested during the semester. Design methods incorporate CAD design tools, implementation with advanced integrated circuit technology and contemporary software tools. Oral and written communication skills are stressed. This is a writing intensive course. (offered fall and spring) (qualifies as a CAP experience) Prerequisites: A grade of $\mathrm{C}$ or better in ENGL 211C or ENGL 221C or ENGL 231C; ECE 341 and ECE 346. Pre- or corequisite: ECE 313. 